\title{
Do French media miseducate the public about intelligence research?
}

\author{
Julien Delhez ${ }^{\mathrm{a}}$ \\ ${ }^{a}$ Georg-August-Universität Göttingen, Germany, delhez.julien@gmail.com, http://orcid.org/0000-0002- \\ 7609-5865
}

\begin{abstract}
This article provides an assessment of French media coverage of intelligence research. The analysis is based on articles published between 1992 and 2020 in French nationwide newspapers, local newspapers and science magazines. Two themes regularly appear in nationwide newspapers and science magazines: environmental effects on $I Q$ and animal intelligence. High-IQ children are often covered in local newspapers. A substantial proportion of articles on the genetics of intelligence, $I Q$ in general and behavioural genetics in general contain statements contradicting the conclusions of mainstream intelligence research; the tendency is even more pronounced in science magazines than in nationwide newspapers. Implications for relationships between scientists and journalists are discussed.
\end{abstract}

Keywords: France, French, intelligence, newspaper, website

\section{Introduction}

Media coverage of a scientific discipline plays a crucial role for researchers. It may have a decisive impact on the funding research projects obtain from governments or the private sector, the moral support researchers can expect from the public at large, and the number of young adults who embrace a scientific career in the field.

While research on human intelligence has seen substantial progress in the last decades (Detterman, 2016), one may ask whether the public has been properly informed. In this regard, France is an interesting country for assessing the role of media: the French are largely underrepresented among researchers on human intelligence. In a recent survey evaluating the views of experts on human intelligence, while $7.67 \%$ of the participants selected the option 'French' for their ethnicity (Rindermann, Becker \& Coyle, 2020, Appendix A, Table A3), not a single expert declared having French nationality (Becker, personal communication). This is surprising given the major role of French psychologists Alfred Binet and Théodore Simon in the early years of intelligence testing (Ritchie, 2015, p. 7).

The present article aims at answering the question: 'Do French media miseducate the public about intelligence research?' To do so, it focuses on articles from the French press and attempts to evaluate their degree of accuracy, as well as the frequency and the nature of the misconceptions they may contain. Here, it is important to note that inappropriate media coverage is not the only hypothesis that might explain French underrepresentation in intelligence research. A proper testing of this hypothesis would require a number of cross-country comparisons, which would go beyond the scope of the present work. Nonetheless, this study may indicate whether such hypothesis is plausible.

\section{Theoretical framework}

I regard science as a human endeavour aiming at 'the accumulation of knowledge by systematic observation, deliberate experiment and rational theory' (Ziman, 1976, pp. 3-4). Science allows for both conceptual progress, i.e. the refinement of categories and concepts used to describe the universe, and explanatory progress, i.e. progress in the understanding of causal patterns (see Kitcher, 1993, pp. 95-112). To understand the scientific endeavour, one needs a realistic understanding of the human beings behind it: they are often influenced by non-epistemic (i.e. non-scientific) factors such as peer pressure, political ideology and cognitive biases. But these social and psychological factors are by no means the only ones driving science, and they should not be seen as preventing any form of scientific progress, objectivity or 


\section{Do French media miseducate the public about intelligence research?}

Delhez

rationality. My own vision of science is best summarized by the words of Philip Kitcher (1993, p. iii): 'Science without legend, objectivity without illusions'.

To be reliable, science must allow for reproducible results and vigorous internal debates. Indeed, critics often lead scientists to reinforce their own arguments. It may happen that a sub-discipline 'is taken over by a particular scientific "paradigm", which then becomes an obstacle to further scientific or technological change' (Ziman, 1994, p. 62) - hence, the benefits of interdisciplinarity, which allows individual researchers to see beyond the boundaries of their own specialties. Interdisciplinarity is closely linked to the ideal of consilience, i.e. the willingness to cross-borders between the humanities, the social sciences and the natural sciences (see Wilson, 1998). Such an effort to cross-borders, aside from leading scientists in various disciplines to inspire one another, also protects scholarship integrity by preventing the creation of insulated intellectual spaces ('echo chambers').

Scientists play a role in communicating their research results to colleagues and to a broader audience. In practice, though, competitiveness in academia puts limits on the time they dedicate to communication with the public - hence, the role of science journalism: science journalists are specialized writers who describe the results of recent research, and the social significance of this research, in a language that needs to be both precise and accessible to non-specialists. Despite the valuable role they may play, science journalists may find themselves at odds with scientists in terms of personal attitude: 'There is a real contradiction between sensationalism and scientific caution, between colourful exaggeration and sceptical precision, between the modesty and impersonality considered appropriate to the scientist and the cult of flamboyant personality of the popular press' (Ziman, 1976, p. 119).

Intelligence research constitutes an interesting case both when it comes to science and when it comes to science journalism. Despite the social and behavioural sciences being sometimes described as less reliable than the physical sciences (see e.g. Ziman, 1976, pp. 281-301; 1978, pp. 158-186), intelligence research may claim to have generated solidly replicated findings, e.g. regarding the heritability of intelligence (see Plomin et al., 2016). Research on the nature of intelligence has led to conceptual progress, and the study of its genetic underpinnings - and, more recently, its neurobiological bases (Haier, 2017) - has led to explanatory progress. Intelligence research is also a highly interdisciplinary area, which draws upon such disciplines as behavioural genetics, evolutionary psychology and the neurosciences. Yet, at least some intelligence researchers seem to be highly concerned about the public perception of their field (see e.g. Gottfredson, 2005, p. 155; 2009, pp. 14-18). A researcher, Earl Hunt, warned: 'We have a communication problem' (Hunt, 2009, p. 324; quoted in Wai, 2020, p. 1). The year 2020 saw two more warnings from Jonathan Wai (2020, p. 1), who wrote that 'communication has been a neglected topic for the field', and Richard Haier (2020, p. 1), who noted that intelligence research 'has a history of intense criticism from non-experts (...)'.

This article may contribute to assessing the magnitude of the 'communication problem' in the French Republic.

\section{Methods}

For the analysis, firstly, I have selected a number of French newspapers in three categories of periodical publications: nationwide generalist newspapers, local generalist newspapers and science magazines. The nationwide generalist newspapers I have selected are L'Express (https://www.lexpress.fr), Le Figaro (https://www.lefigaro.fr), Le Journal du Dimanche (https://www.lejdd.fr), Le Monde (https://www.lemonde.fr), Le Point (https://www.lepoint.fr), Libération (https://www.liberation.fr), Marianne (https://www.marianne.net), Le Nouvel Observateur (https://www.nouvelobs.com) and Valeurs actuelles (https://www.valeursactuelles.com). The local generalist newspapers I have selected are Dernières Nouvelles d'Alsace (https://www.dna.fr), La Voix du Nord (https://www.lavoixdunord.fr), Le Dauphiné Libéré (https://www.ledauphine.com), Le Parisien (https://www.leparisien.fr) and Nice-Matin (https://www.nicematin.com). The science magazines I have selected are Cerveau et Psycho (https://www.cerveauetpsycho.fr) and La Recherche (https://www.larecherche.fr).

Secondly, within these periodical publications, I have sought to retrieve articles dealing with the field of intelligence research. This includes articles covering recent discoveries, presenting the state of knowledge about specific issues, or discussing the social significance of findings in intelligence research. As a general rule, the newspapers and magazines listed above publish their articles both in print form and on their websites. I have retrieved the articles from the websites, both with the tools provided by the websites themselves (e.g. keyword search) and with the function 'site:' of search engines. For instance, in the Startpage search engine (https://www.startpage.com), searching for 'intelligence site:www.lemonde.fr' will provide links to articles available on www.lemonde.fr and including the word 'intelligence'. The keywords or key expressions I have used are the French words or expressions 'intelligence' (same meaning in English), 'quotient intellectuel' (intellectual quotient), 'intelligent' (same meaning in English) and 'QI' (IQ).

Thirdly, having obtained the internet links, I have retained the articles that were relevant and excluded the irrelevant ones. For instance, since intelligence research includes research on intelligence in non-human animals (which helps answering question about human intelligence, see Arden, 2019) but not research on artificial intelligence, I have retained the articles on animal intelligence but not those on artificial intelligence. Besides, I have excluded articles reporting anecdotes or focused on a single individual and devoid of scientific content (e.g. articles about, say, a high-IQ child 


\section{Do French media miseducate the public about intelligence research? \\ Delhez}

obtaining his secondary school degree at age eight). However, I did retain articles dedicated to individual intelligence researchers. In exceptional cases, I have included articles that, without containing words such as 'intelligent', discuss concepts and methods of behavioural genetics which are important for intelligence research, e.g. the heritability concept, twin studies or various methods (these articles constitute the category: 'behavioural genetics in general'). The reason for this choice is that such articles inevitably have an impact on the perceived credibility of intelligence research.

Fourthly and finally, I have analysed the content of the articles I retained. On the one hand, in order to assess the representativeness of the French media coverage, I have established a list of topics within intelligence research, e.g. animal intelligence, and I have assessed the number of articles dedicated to each topic. On the other hand, in order to assess the accuracy of the French media coverage, I have identified the statements that, in these articles, contradict mainstream intelligence research as represented, e.g., by Gottfredson (1997) and Ritchie (2015) and the statements that constitute myths or fallacies on intelligence as analysed and refuted by Warne (2020). The complete list of articles (published between 1992 and 2020), including a list of articles containing myths or fallacies, is available upon request.

\section{Results}

The focus of newspaper articles on intelligence differs depending on the type of newspaper. For generalist newspapers $(\mathrm{N}=231$; see Fig. 1), more than $50 \%$ of articles touch on one of the five following topics: environmental effects on IQ, real or supposed (49 articles); the intelligence of non-human animals (23 articles); high-IQ children and their difficulties at school (22 articles); cognitive enhancement, genetic or non-genetic (18 articles); and the anti-Flynn effect, i.e. the recent losses of IQ observed in France and elsewhere (16 articles). With regard to the last, all articles except one offer an environmental explanation for the phenomenon. Thus, 53 articles $(38+15)$ address environmental effects on intelligence. Moreover, when one takes into account both the articles focused on high-IQ children and those focused on high-IQ adults, it appears that 30 articles $(22+8)$ discuss high-IQ individuals and their life outcomes.

Fig. 1 Coverage of intelligence research in French nationwide generalist newspapers.

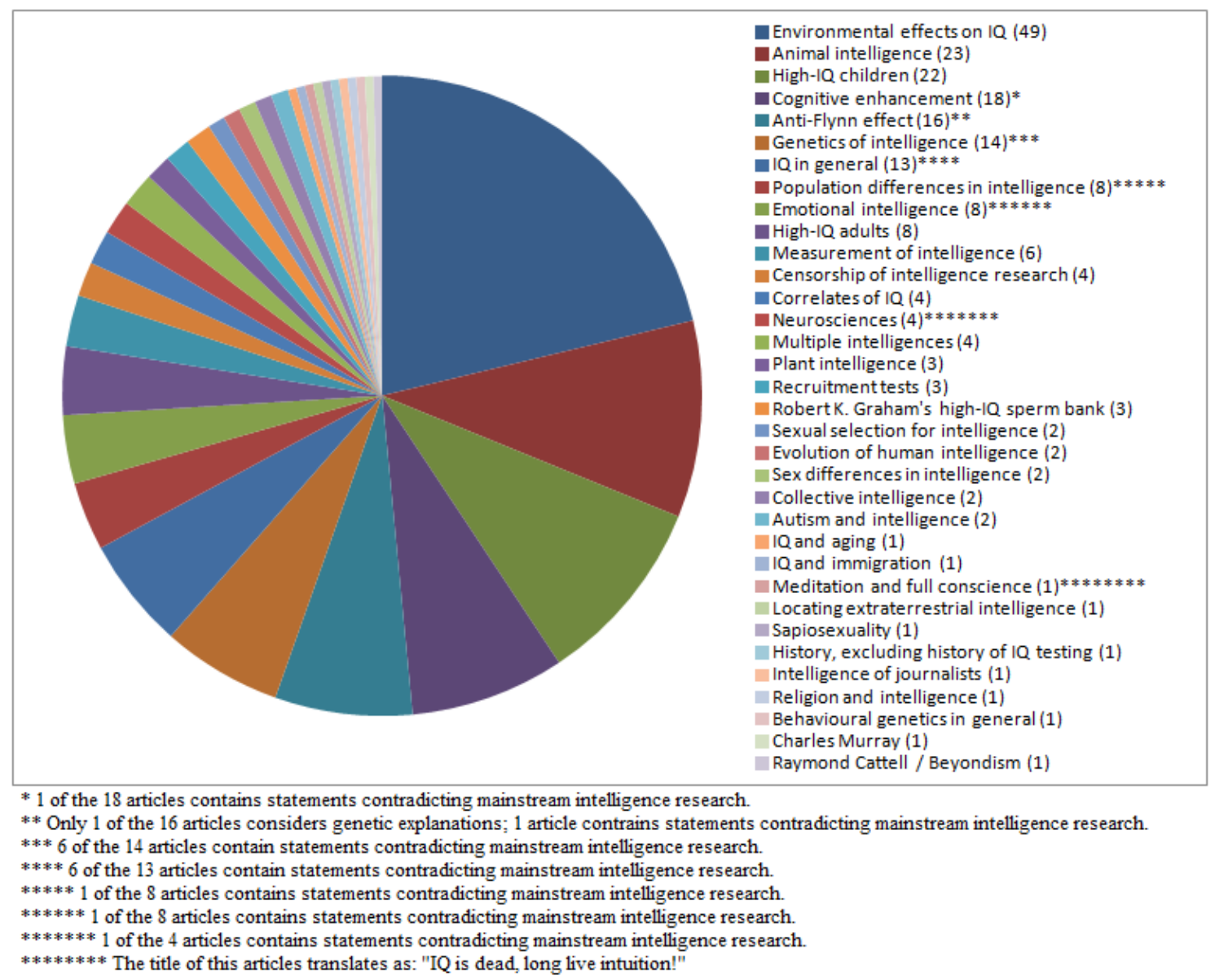

French local newspapers (see Fig. 2) contain few articles on human intelligence ( $\mathrm{N}=17)$. Hence, one should be careful with the interpretation of the results. Nonetheless, articles on high-IQ children seem to be well represented, making $41.18 \%$ of the total ( 7 articles). Finally, articles in science magazines ( $=179$; see Fig. 3), which seem to offer the most 


\section{Do French media miseducate the public about intelligence research? \\ Delhez}

diverse choice of topics, often deal with animal intelligence (38 articles) and environmental effects on intelligence (17 articles).

Fig. 2 Coverage of intelligence research in French local newspapers.

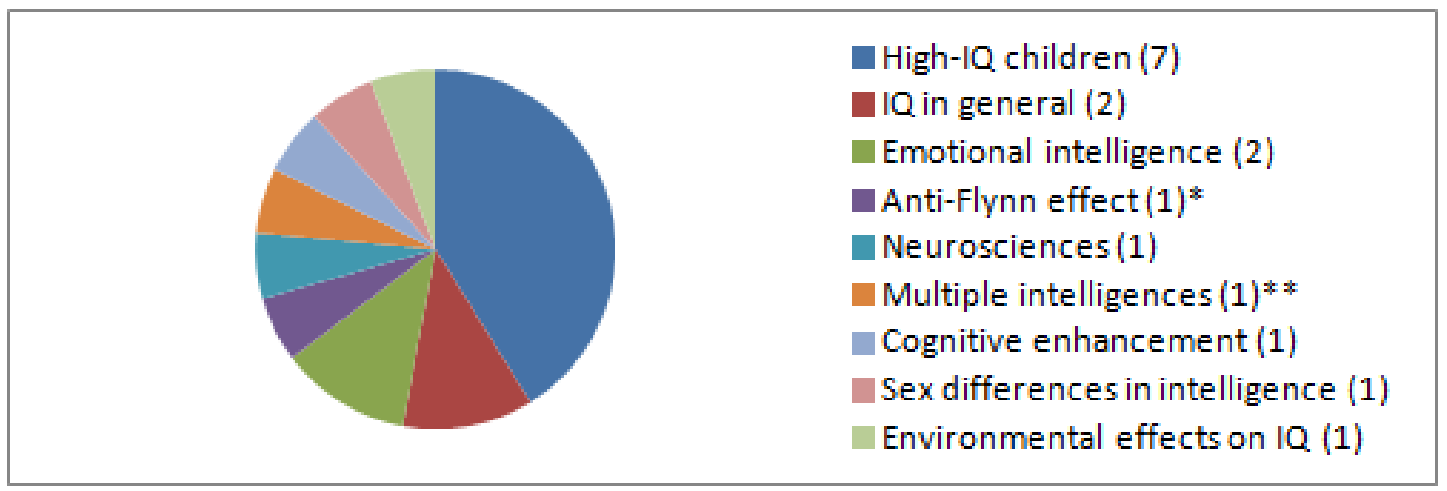

* The article only considers environmental explanations for the phenomenon.

** The article does not mention or allude to Howard Gardner.

Fig. 3 Coverage of intelligence research in French science magazines.

The figures provided for the three categories of media coverage show that an appreciable proportion of articles focus on non-mainstream approaches to intelligence, e.g. emotional or multiple intelligences. In addition, among articles dedicated to IQ in general, to the genetics of intelligence and to behavioural genetics in general, a substantial proportion

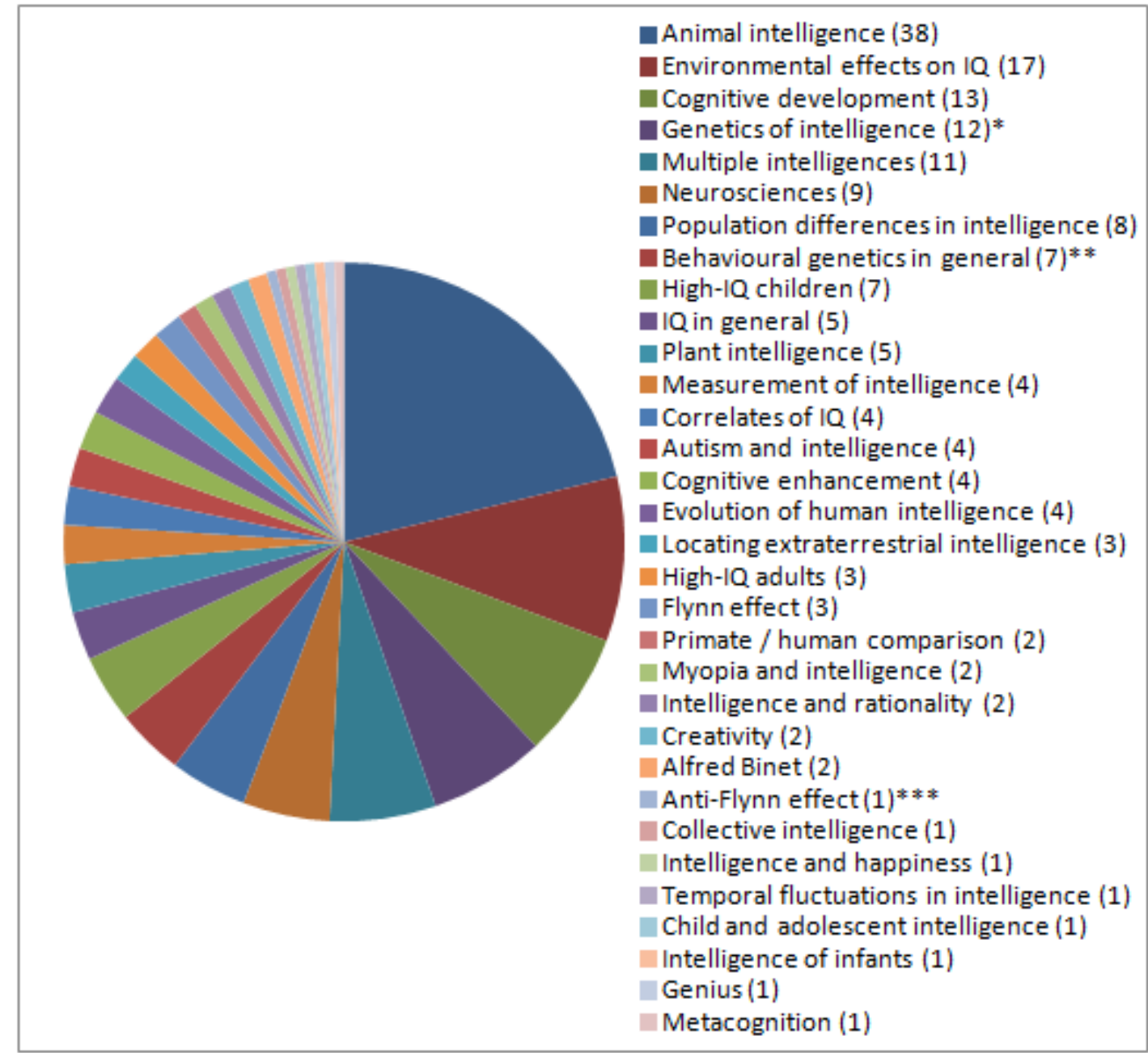

* Of 12 articles, 6 contain statements that contradict mainstream intelligence research.

** All 7 articles contain statements that contradict mainstream intelligence research.

*** The article only considers environmental explanations for this phenomenon. 


\section{Do French media miseducate the public about intelligence research? \\ Delhez.}

contain statements explicitly contradicting the findings of mainstream intelligence research. For articles in nationwide generalist newspapers (see Fig. 4), the overall percentage is 42.86\% (12 of 28 articles). The tendency is even more pronounced in science magazines (see Fig. 5), with a percentage of 54.17\% (13 of 24 articles). Noticeably, the prevalence of such articles differs over years: among science magazines, the percentage of articles contradicting mainstream science on intelligence reaches $70.9 \%$ in the 1990 (12 of 17 articles) but falls down to $7.14 \%$ after 2010 ( 1 of 7 articles). The tendency is less pronounced for nationwide newspapers, whose interest in intelligence research seems to have grown recently.

Fig. 4 Nationwide newspaper articles on IQ and behavioural genetics contradicting mainstream intelligence research.

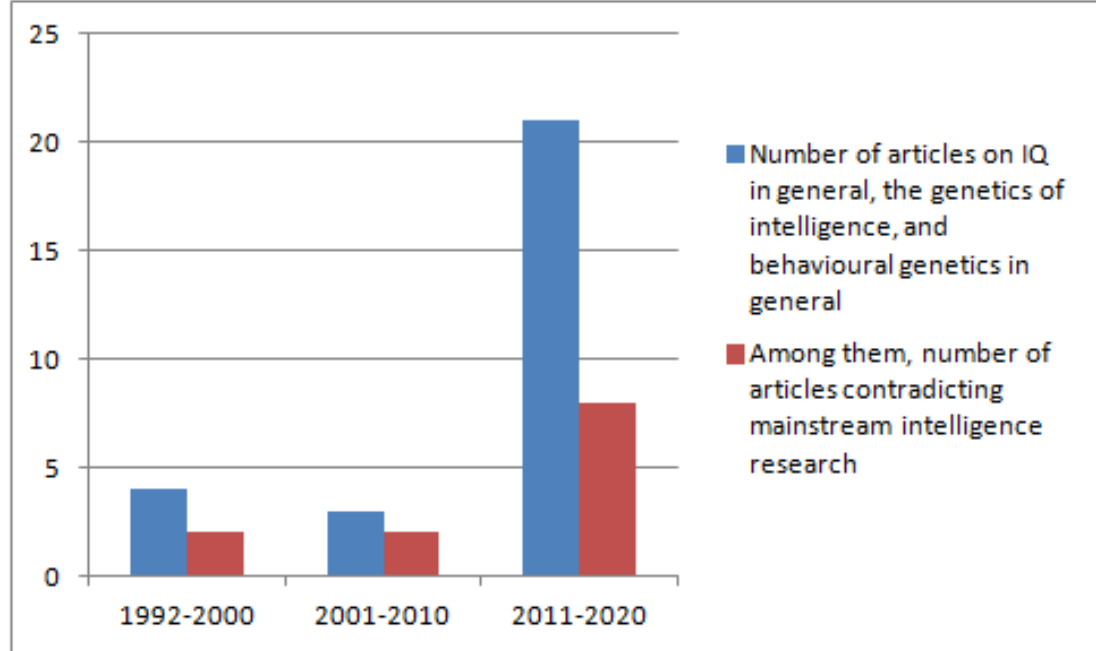

Fig. 5 Science magazine articles on IQ and behavioural genetics contradicting mainstream intelligence research.

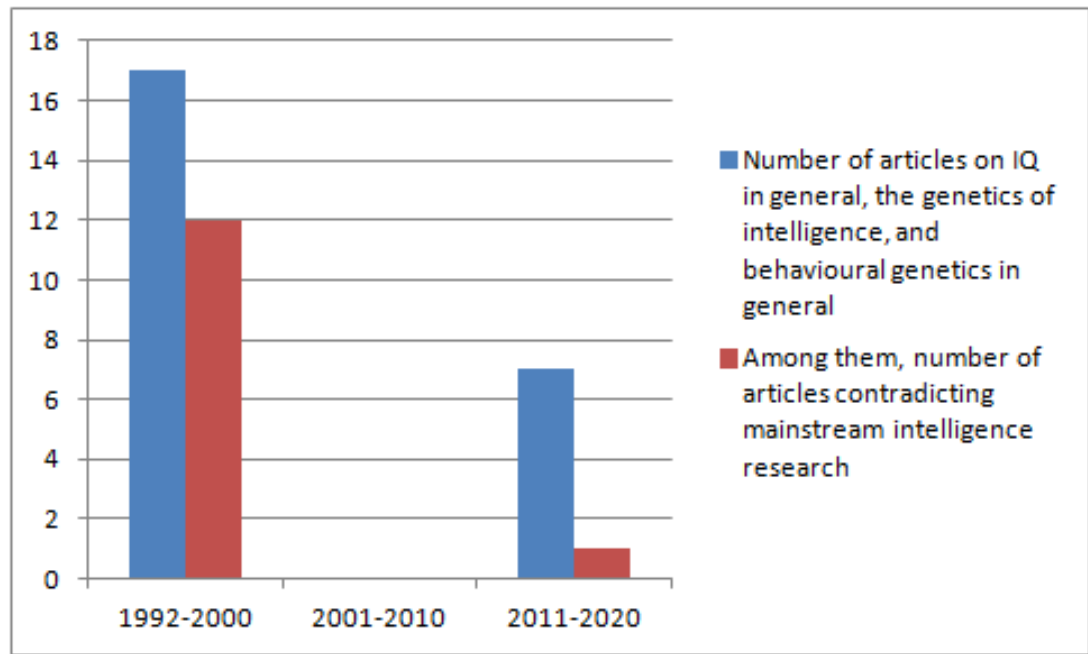

A complete list of the myths and fallacies present in these articles would require considerable space. Instead, I will provide a list and a discussion of those that appeared in two generalist newspapers: L'Express and Le Monde.

Here, I want to stress that I did not establish a personal list of fallacies. Instead, I have used Gottfredson's list of statements representing mainstream intelligence research (Gottfredson, 1997) and Warne's list of myths about IQ and intelligence research. Despite these lists having been established outside of France, they turned out to be appropriate for classifying the fallacies in articles from these two French newspapers. One may be tempted to say that these myths know no borders.

Table 1 suggests that the fallacies generally work in the same direction, that is: they devaluate intelligence research, not least by devaluating IQ tests as an instrument (myths no 2, 5 and 7), and they minimize the role of genetic factors (myth no 13). The idea that intelligence research leads to negative policies (myth no 33) seems especially recurrent. 


\section{Do French media miseducate the public about intelligence research? \\ Delhez}

Table 1. Myths or fallacies about human intelligence in two nationwide generalist newspapers.

\begin{tabular}{ll}
\hline Article & URL \\
\hline Le QI, c'est bête & https://www.lexpress.fr/informa \\
(Bruno D. Cot, 21 & tions/le-qi-c-est- \\
March 2002) & bete 647713.html
\end{tabular}

Statement
"Ces tests donnent une indication
limitée à une aptitude logique et
mathématique, alors qu'il existe d'autres
formes d'intelligence: musicale,
linguistique, intuitive ou encore
spatiale», précise le psychologue Olivier
Houdé.

Myth/fallacy type

IQ tests only measure narrow academic skills (statements no 1 and 2 in Gottfredson, 1997); multiple intelligences (myth no 5 in Warne, 2020) Houdé.

"ll y a dans ces démarches un relent d'élitisme, condamne Jacques Lautrey, professeur de psychologie à l'université René-Descartes (Paris V). (...).»

Émotion et intelligence

(Ariane

Poulantzas, 1

February 1999)

L'hérédité explique-t-elle tout? (Françoise

Harrois-Monin, 28

October 1993)

Génétique : enquête sur un dérapage (Charles Gilbert, 17

December 1992)

Transmission de l'intelligence par la mère, une fausse information qui refait surface (Gary Dagorn, 4 February 2020)

Génomique à grande échelle, un bilan en demiteinte (Florence Rosier, 10 September 2018)

Réussite scolaire : «Rien ne permet d'affirmer que le QI est lié pour 50 $\%$ au patrimoine génétique " (Julien Larregue, 20 May 2018)

Non, la mère ne transmet pas seule l'intelligence aux enfants (Gary Dagorn, 28 September 2016) https://www.lexpress.fr/culture/ ivre/l-esprit-quiapprend 802957.html

https://www.lexpress.fr/informa tions/l-heredite-expli-que-telle-tout 605862.htm

https://www.lexpress.fr/informa tions/genetique-enquete-surun-derapage 592392.htm

https://www.lemonde.fr/lesdecodeurs/article/2020/02/04/t ransmission-de---intelligencepar-la-mere-une-fausseinformation-qui-refaitsurface $6028375 \quad 4355770$. ht $\mathrm{ml}$

https://www.lemonde.fr/scienc es/article/2018/09/10/genomia ue-a-grande-echelle-un-bilanen-demi-

teinte 5353150 1650684.htm full article available at:

https://www.univbrest.fr/digitalAssets/72/72415 GENOMIQUE-DE-MASSEpour-PREDIRE-les--

MALADIES-

FREQUENTES.pdf )

https://www.lemonde.fr/idees/a rticle/2018/05/20/reussite-

scolaire-non-la-genetique-nedetermine-pas-

tout $53018593232 . \mathrm{html}$ (full article available at:

https://twitter.com/JulienDLarr egue/status/99777622106802 9952/photo/1)

https://www.lemonde.fr/lesdecodeurs/article/2016/09/28/ non-la-mere-ne-transmet-pas-intelligence-auxenfants 5005012 4355770.ht $\underline{\mathrm{ml}}$
II n'y a qu'à voir les tests de QI (quotient intellectuel) censés mesurer

l'intelligence pour s'en apercevoir: ce sont surtout des aptitudes logiques qui les intéressent.

L'eugénisme déjà pointait le nez. II réapparaîtra, jusqu'à la tragédie, plusieurs fois au cours de l'Histoire. Qu'on se souvienne des querelles épiques sur l'inné et l'acquis.

... le quotient intellectuel (QI) - qui est loin de définir l'intelligence ...

... de telles recherches ne sont jamais neutres et ne se limitent pas à la connaissance pure. Qu'on le veuille ou non, celles-ci déboucheront tôt ou tard sur des applications pratiques qui donnent froid dans le dos.

... la transmission génétique joue un rôle moins important dans la détermination des capacités cognitives que ce que l'on pensait. Estimé de $70 \%$ à $75 \%$ il y a encore trente ans, le rôle de la génétique est aujourd'hui évalué approximativement entre $20 \%$ et $40 \%$.

Quid, enfin, des GWAS sur le

déterminisme génétique de

"l'intelligence » humaine ? Sujet des plus périlleux. Ce qui ne décourage pas certains chercheurs de se lancer dans l'aventure, comme Robert Plomin, du King's College à Londres, qui explore la part des gènes dans le quotient intellectuel (QI). "L'intelligence est un trait si stigmatisant, et dont le QI ne saisit qu'une part si limitée, qu'il vaudrait mieux se garder de ces recherches", estime Xavier Jeunemaître.

Bien sûr, l'accompagnement de ces personnes pourra par la suite être individualisé, mais l'individu sera stigmatisé et ramené à ces quelques facteurs de risque méta-individuels. [about low-IQ individuals]

... la transmission génétique joue un rôle moins important dans la détermination des capacités cognitives que ce que l'on pensait. Estimé de $70 \%$ à $75 \%$ il y a encore trente ans, le rôle de la génétique est aujourd'hui évalué approximativement entre $20 \%$ et $40 \%$.
Intelligence research leads to negative policies (myth no 33 in Warne, 2020)

IQ tests only measure narrow academic skills (statements no 1 and 2 in Gottfredson, 1997)

Past controversies taint intelligence research (myth no 32 in Warne, 2020)

Measuring intelligence is difficult (myth no 7 in Warne, 2020)

Intelligence research leads to negative policies (myth no 33 in Warne, 2020)

Genes are not that important (statement no 14 in Gottfredson, 1997, myth no 13 in Warne, 2020)

Intelligence cannot be captured with one number, IQ (myth no 2 in Warne, 2020); intelligence research leads to negative policies (myth no 33 in Warne, 2020)

Intelligence research leads to negative policies (myth no 33 in Warne, 2020)

Genes are not that important (statement no 14 in Gottfredson, 1997, myth no 13 in Warne, 2020) 


\section{Do French media miseducate the public about intelligence research? \\ Delhez.}

Q.I.: la grande illusion (Annick Cojean, 30 April 2007) https://www.lemonde.fr/vous/a rticle/2007/04/30/q-i-la-grandeillusion 903695 3238.htm
Encore faudrait-il que les parents (...) abandonnent l'obsession du fameux Q.I., cette évaluation intellectuelle et psychologique quantitative, objet de mille malentendus et tellement réductrice.

Fini, l'usage d'un chiffre unique pour traduire une intelligence que l'on sait désormais multidimensionnelle!
Intelligence cannot be captured with one number IQ (myth no 2 in Warne, 2020)

\section{Discussion}

These results have limitations that must be taken into account. Firstly, some of the media outlets mentioned above are far more influential than others (e.g. Le Figaro, Le Monde). Secondly, within the same newspaper or magazine, some articles may receive more visibility than others due to factors such as length, author prominence, article type (e.g. correspondence piece, book review and opinion) and sharing on social networks. The number of articles dedicated to a specific area of intelligence research is, therefore, an imperfect indicator of the attention received by this area.

Nonetheless, the overall number of French articles examined here $(\mathrm{N}=427)$ is sufficient to warrant at least tentative suggestions. Thus, one may now come back to the initial question: 'Do French media miseducate the public about intelligence research?'

When it comes to the issue of representativeness, it seems that all categories of newspapers and magazines primarily publish articles on issues perceived as relevant for their readership. For instance, the fate of high-IQ children and adults is regularly debated, especially in the local press. Likewise, the most discussed theme of nationwide newspapers, environmental effects on IQ, is of immediate importance for the population at large. Topics of scientific interest but whose relevance for today may be less obvious to non-specialists, e.g. the neurosciences or the evolution of human intelligence, are mostly discussed in scientific magazines. Thus, the image of intelligence research given by the French press may be somewhat unrepresentative.

When it comes to accuracy, the results above call for some nuance: it must be acknowledged that most articles do not contain fallacies about human intelligence. Nonetheless, three observations need to be made: (1) a substantial minority of articles do convey fallacies about intelligence research, and the percentage is especially high for articles on IQ in general and for articles on the genetics of intelligence; (2) as noted above, the fallacious statements tend to work in the same direction and, therefore, to strengthen one another; (3) during the collection of articles on human intelligence, I have found only four articles denouncing the censorship of intelligence research, or hostility to it; thus, while a substantial number of articles have spread myths about human intelligence, far fewer articles have attempted to counter them.

In conclusion, most articles do not individually miseducate the French public on human intelligence. However, given the non-negligible number of articles with statements contradicting mainstream intelligence research, the recurrence of such statements and the rarity of articles refuting them, one may think that the present state of the French media as a whole contributes to the French being miseducated about intelligence research. This situation need not be seen as irredeemable. Indeed, articles spreading misconceptions about intelligence are less frequent today than in the nineties. Nonetheless, such articles may continue to shape public opinion years after their original publication date. Finally, given these results, it seems plausible that the current French media coverage, by fostering distrust towards specialists of human intelligence, contributes to the French being underrepresented in the field of intelligence research.

Many other means can be thought of to assess how the French media meet (or fail to meet) their mission of educating the public about human intelligence. The present work only constitutes a first step towards understanding, and possibly reducing, the knowledge gap between the world of intelligence research and the world of journalism in France.

\section{References}

Arden, R. (2019). Cognitive abilities in other animals: An introduction to this special issue. Intelligence, 74, 1-2. https://doi.org/10.1016/j.intell.2019.04.003

Detterman, D.K. (2016, July), Intelligence research: 50 years of satisfaction. President's invited address at the 17th Annual Conference of the International Society for Intelligence Research (ISIR), Saint-Petersburg, Russia. Retrieved from https://www.youtube.com/watch?v=UF72oeDwbQU

Gottfredson, L.S. (1997). Mainstream science on intelligence: An editorial With 51 signatories, history, and bibliography. Intelligence, 24, 13-23. https://doi.org/10.1016/S0160-2896(97)90011-8

Gottfredson, L.S. (2005). Suppressing intelligence research: Hurting those we intend to help. In R.H. Wright é N.A. Cummings (Eds.), Destructive trends in mental health: The well-intentioned path to harm (pp. 155-186). New York: Taylor \& Francis. 


\section{Do French media miseducate the public about intelligence research? \\ Delhez}

Gottfredson, L.S. (2009). Logical fallacies used to dismiss the evidence on intelligence testing. In R. Phelps (Ed.), Correcting fallacies about educational and psychological testing (pp. 11-65). Washington, DC: American Psychological Association.

Haier, R.J. (2017). The Neuroscience of Intelligence. Cambridge: Cambridge University Press.

Haier, R.H. (2020). Academic freedom and social responsibility: Finding a balance. Intelligence, 82, 101482. http://dx.doi.org/10.1016/j.intell.2020.101482

Hunt, E. (2009). Good news, bad news, and a fallacy: A review of Outliers: The story of success. Intelligence, $37,323-$ 324. http://dx.doi.org/10.1016/j.intell.2009.03.003

Kitcher, Ph. (1993). The Advancement of Science: Science without Legend, Objectivity without Illusions. New York Oxford: Oxford University Press.

Plomin, R., DeFries, J.C., Knopik, V.S. \& Neiderhiser, J.M. (2016). Top 10 Replicated Findings from Behavioral Genetics. Perspectives on Psychological Science, 11(1), 3-23. https://dx.doi.org/10.1177\%2F1745691615617439

Rindermann, H., Becker, D., \& Coyle, T.R. (2020). Survey of expert opinion on intelligence: Intelligence research, experts' background, controversial issues, and the media. Intelligence, 78, 101406. https://doi.org/10.1016/j.intell.2019.101406

Ritchie, S. (2015). Intelligence: All That Matters. London: John Murray Learning.

Wai, J. (2020). Communicating intelligence research. Journal of Intelligence, 8 , 40. https://doi.org/10.3390/jintelligence8040040

Warne, R.T. (2020). In the Know: Debunking 35 Myths about Human Intelligence. Cambridge: Cambridge University Press.

Wilson, E.O. (1998). Consilience: The Unity of Knowledge. New York: Vintage Books.

Ziman, J. (1976). The Force of Knowledge: The scientific dimension of society. Cambridge: Cambridge University Press.

Ziman, J. (1978). Reliable knowledge: An exploration of the grounds for belief in science. Cambridge: Cambridge University Press.

Ziman, J. (1994). Prometheus Bound: Science in a dynamic steady state. Cambridge: Cambridge University Press. 